\author{
R.K. Yelshibayev ${ }^{1, *}$, S.B.Sauranbai ${ }^{2}$, A.O.Agymbai ${ }^{3}$ \\ ${ }^{I}$ Narxoz University, Almaty, Kazakhstan, \\ ${ }^{2}$ KazNRU, Almaty, Kazakhstan \\ ${ }^{3}$ University of Foreign Languages and Professional Career, Almaty, Kazakhstan \\ ${ }^{1}$ E-mail: rakymzhan.yelshibayev@bk.ru, ${ }^{2}$ E-mail: bss0609@mail.ru, ${ }^{3}$ E-mail: agymbai@mail7ru \\ ${ }^{1}$ htpp://orcid.org/0000-0001-7119-7400, ${ }^{1}$ Scopus AuthorID: 57217823785
}

\title{
State regulation of the securities market of the Republic of Kazakhstan
}

\begin{abstract}
Object: The purpose is to identify promising directions for the development of the securities market of the Republic of Kazakhstan and reform the system of its government regulation.

Methods: The study used methods of empirical, subject-object, system, deductive and comparative analysis. Each of these methods was used adequately to its functional capabilities and resolving abilities for solving the corresponding stage research tasks.

Findings: As a result of the research by the author:

- features of the securities market as an object of government regulation are studied;

- infrastructure support of the system of government regulation of the securities market of the Republic of Kazakhstan was examined;

- assessment of the current state of the securities market of the Republic;

- system problems of government regulation and market development are investigated;

- promising areas of reforming the securities market of the Republic of Kazakhstan and its government regulation system are developed and scientifically substantiated.

Conclusions: A shift of focus from problems of legal support of the system of government regulation of the securities market of the Republic of Kazakhstan to the problem of primary transparency and reliability of the market in terms of economic integration and global coronacrisis will allow achieving the following targets:

- share market capitalization to GDP will double if new IPOs are held by corporate issuers;

- RFCA will join the group of ten leading financial centers in Asia;

- access to financial services for a wide range of consumers will be provided;

- increase of financial literacy of the population, protection of interests of potential investors and safety of savings of market participants will be ensured.

Keywords: government regulation, securities market, investment climate, market capitalization, Kazakhstan stock exchange (KASE), institutional investors, professional market participants, financial literacy.
\end{abstract}

\section{Introduction}

In the Plan of Nation "100 Specific Steps to Implement 5 Institutional Reforms" by Elbasy Nursultan Nazarbayev, the regulation and development of the securities market is considered as one of the effective government measures to improve the financial sector of the Republic of Kazakhstan. Speaking at the Astana economic forum, the Leader of the Nation has quoted this clause, having noted that"there are no more oil super-profits now, so one of the alternative sources of financing industrial and innovative development of the state should be the improvement of mechanisms for attracting the temporarily free financial resources from the people". Thereby N.A. Nazarbayev has set the direction of the further work for the representative and executive authorities of the Republic.

Following the points outlined by Elbasy in the policy document, now the Government spends significant amounts from the republican budget to finance work on studying the promising courses of development of the securities market of the Republic. Great attention is paid to the issues of improving the financial literacy of people. The implementation of the People's IPO program continues, which consists in the public placement of share of the large domestic companies for sale to the general public of Kazakhstan. But despite

\footnotetext{
${ }^{*}$ Corresponding author.

E-mail address: rakymzhan.yelshibayev@bk.ru
} 
this fact, government regulation has a number of serious problems associated with hard regulatory infrastructure, as well as excessive attention to the professional players of the securities market.

For a relatively short period, the Parliament of Kazakhstan has developed 59 improved laws and regulations, a significant part of which forms a completely new legal environment in the system of economic relations regarding the issue and trading of securities. However, the lack of a systemic approach to the regulation and development of the securities market, as well as the modern trends caused by the global coronacrisis, directed the activities of the central authorities towards the adaptation of the domestic market to the crisis conditions, as a result of which the current securities market of Kazakhstan does not fulfill itsinvestment function, but serves mostly as an object of speculative operations.

Considering the foregoing, we have to state the lack of fundamental studies in the field of government regulation and the development of the securities market, which determines the relevance of the topic of the scientific publication.

The hypothesis of the authors consists in the assumption that the shift of the focus from the problems of legal support of the system of state regulation of the securities market of the Republic of Kazakhstan to the problem of primary transparency and reliability of the market from the point of view of potential investors will serve as an evolutionary trigger of its intensive development.

\section{Literature Review}

In recent years, many domestic scientists and practitioners study the modern securities market and the mechanisms of itsfunctioning. Modern Russian researchers often touch upon the issues of the development of the securities market. This problem can be found in the works by P.Abbassi, R. Iyer, J-L.Peydró, F. R.Tous, (Abbassi,Iyer,Peydro,Tous,2016),J.M. Bottazzi, J. Luque, M.R. Pascoa (Bottazzi, Luque, Pascoa, 2012) andM.Cabán-García, (Cabán-García, 2011). T.Lohse, R. Pascalau, (Lohse, Pascalau, 2014), J. Luque, M. R. Páscoa, (Luque, Páscoa, 2014), M.Magill, M. Quinzii (Magill, Quinzii, 2011), J.L. Teall (Teall, 2013).

Special attention should be paid to M. Golovnin (Golovnin,2016), R. Erkebaev (Erkebaev,2016), R Miller (2016), L. Zhumabekov (Zhumabekov,2020), who deal with the study of the processes of merging the markets of Russia and Kazakhstan. The mentioned scientific papers constitute the core methodological basis for understanding the specific features of the organization of the securities market.

The works dedicated to the issues of government regulation and development of the securities market in Kazakhstan include the studies by G. Karagusova (Karagusova,2020), B. Yesenov (Yesenov,2019), S.V. Agaltsova (Agaltsova, 2020), etc. It should be noted that most of the mentioned papers mainly consider ways to improve the well-being of the people by creating a favorable investment climate in the country. They also cover other important issues, but in general, we can speak of the lack of specific proposals that can fundamentally change the current situation in the securities market.

\section{Methods}

The study used methods of empirical, subject-object, system, deductive and comparative analysis. Each of these methods was used adequately to its functional capabilities and resolving abilities for solving the corresponding stage research tasks.

The use of empirical and theoretical methods in this study made it possible toconduct a more detailed study of theeconomic essence of the securities market of the Republic of Kazakhstan as an object of state regulation.

In the course of examination of the infrastructural support of the system of sgovernment regulation of the securities market of the Republic of Kazakhstan, the method of collection of information, and, partially, the abstraction method for effective search, grouping, processing, and generalization of the necessary material was used.

Having studied the main economic indicators of the market, the authorsp roceeded to the use of systemic and comparativere search methods, in the course of which they have analyzed and assessed the current state of the securities market of the Republic. The systemic problems of government regulation and market development were identified.

Finally, the use of the induction method allowed to formulate the main conclusions of the study of the process of development of the securities market of the Republic of Kazakhstan as an object of government regulation. At the same time, the abstraction method allowed us to exclude in significant characteristics in 
the regulation and development of the market and thereby focus on its most promising areas of reforming, which include: increasing the stability and efficiency of the securities market in the context of economic integration and global coronacrisis, improvement of the government regulation infrastructure and creation of the optimal conditions for the qualitative development of the securities market, broadening of the potential of the securities market, including through the financial products the meet the needs of the modern economic situation in Kazakhstan.

The authors have also used the expert assessments of independent researchers and materials published in public electronic sources: www.kase.kz, www.kazpravda.kz, www.newskaz.ru, www.online.zakon.kz, www.vesti.kz, www.kaztag.kz, www.sciencedirect.com.

The common logic of the work is based on the complex and systemic approach with the use of the modern scholarly apparatus.

\section{Results}

The securities market is a set of economic relations regarding the issue and trading of securities between its subjects: issuers, investors, and professional market players.

The market players, who are both issuers and traders, are conventionally divided into several groups.

1. Financial institutions conducting securities transactions: commercial and investment banks, insurance companies, pension funds, etc.

2. Individual investors - individuals, including owners of small venture enterprises.

3. Professional players of securities market: brokers (intermediaries who carry out transactionsat the expense and on behalf of the client) and dealers (intermediaries who carry out transactions at their own expense andin their own name).

4. State, local executive bodies, largest national and international companies(Miller, 2016).

Government regulation of the securities market-actions of organizations authorized by the state aimed at adjusting the actions of the securities market players.

The main goal of government regulation is the maintenance of the efficiency of functioning and further development of the securities market through:

- ensuring order and favourable working conditions for all market players;

- control over pricing in the market based on real supply and demand;

- creation of an efficient mechanism of redistribution of the fictitious capital that has the potential for adequate compensation of risks of the market players;

- protection of the market players from various fraudulent actions of counterparties: unfair competition, trade in insider information, fraud, etc.;

- reasonable taxation of the securities sector;

- organization of the new markets, support of their structures, initiatives and innovations;

- prevention of infringement of public interest in the course of development of the securities market.

In accordance with the Law "On the Securities Market", the government regulation authorities are designed to solve the following tasks:

- establish the mandatory requirements to the activities of the issuers and the professional players of the securities market, as well as its standards;

- registration of the issues of securities and issue prospectus; control over the compliance by the issuers with the terms and obligations provided for in these documents;

- licensing of the activities of the professional players of the securities market;

- creation of the system for the protection of the rights of owners and control over observance of their rights by the issuers and professional players of the financial market;

- prohibition and suppression of activities of the persons engaged in unlicensed entrepreneurial activities, as well as the organization of the system for improving the levels of proficiency and education of securities market players. 
There are many ways of government regulation of the securities market (Fig. 1).

1. In terms of goals and methods: external and internal

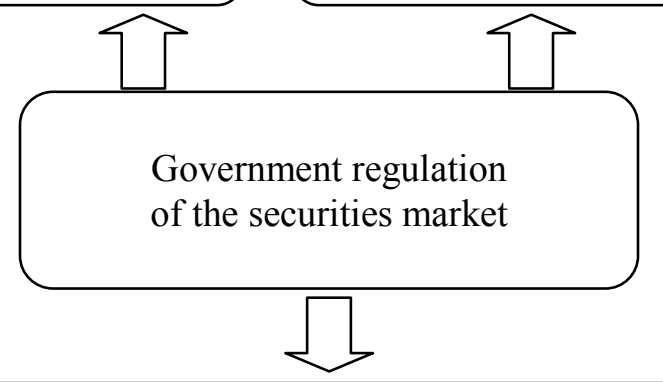

3. Depending on the object carrying out regulation: government regulation, regulation by the professional market players or market self-regulation

Figure 1. Government regulation of the security market

Note-prepared by the authors based on (Lohse, Pascalau, 2014, 199-200)

The infrastructure of the government regulation of the security markets of the Republic of Kazakhstan is represented by the following bodies - Figure 2 .

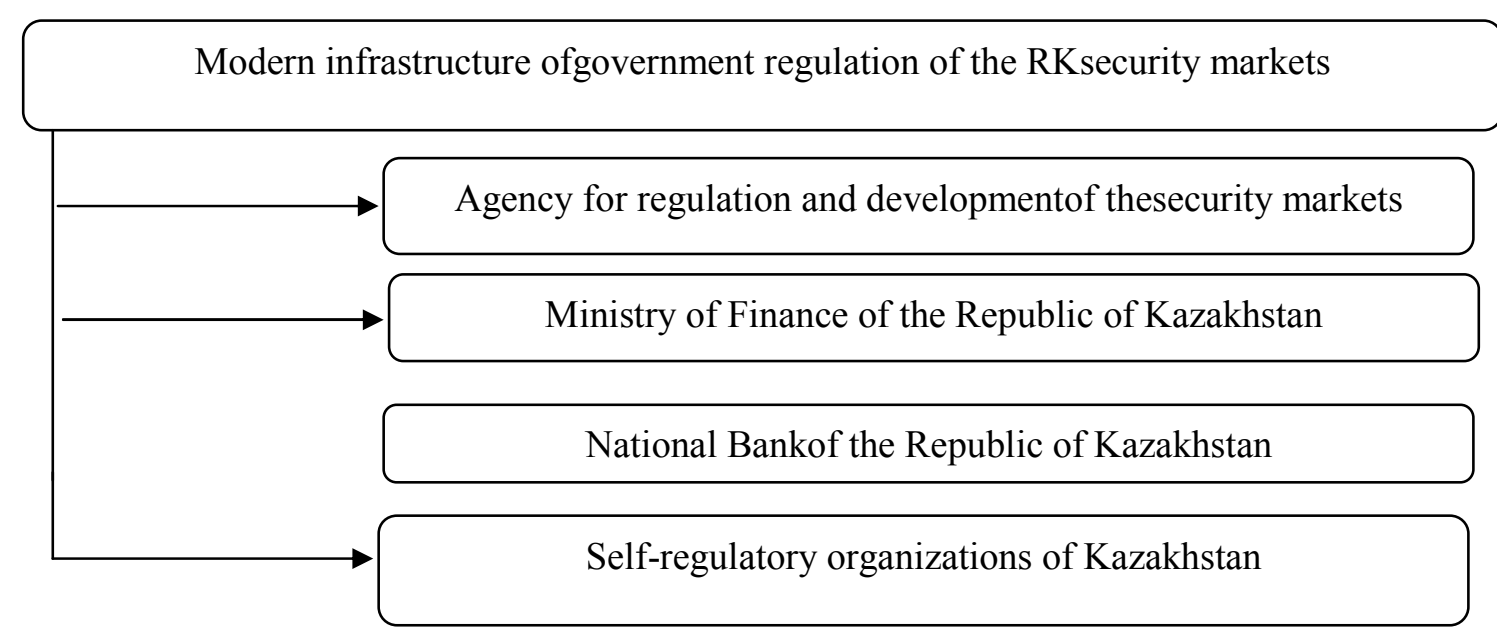

Figure 2. Infrastructure of the government regulation ofthe security markets of RK

Note-prepared by the authors

The securities market can also be regulated with the help of the market players themselves. For this purpose, the professional market players (brokers and dealers) unite into non-profit organizations. The goal of such organizations is participation in the process of regulating the security markets together withstate regulatory bodies. In this case, the state delegates them a part of its regulating functions. However, these organizations cannot be called public; they areself-regulatory organizations (SRO) (Cabán-García, 2011, 284).

In Kazakhstan, the only full-fledged self-regulatory organization is the Kazakhstan Stock Exchange (KASE). The KASE index is the key indicator characterizing the dynamics of development of the securities market of Kazakhstan.

The government securities are nothigh-yielding, but they have a high degree of reliability, and, therefore, there are always social groups (retired persons, single persons, families without a bread winner,etc.), who do not want to risk and prefer to invest their funds in such securities. 
In the author's opinion, to assess the efficiency of the government measures for regulation and development of the market it is necessary to focus onthe more dynamic market of non-public securities and its institutional investors.

Table 1. Number of institutional investors and the size of their assets

\begin{tabular}{|c|c|c|c|c|c|c|}
\hline \multirow{2}{*}{$\begin{array}{l}\text { Types of institutional } \\
\text { investors }\end{array}$} & \multicolumn{2}{|c|}{$\begin{array}{l}\text { Number of institutional } \\
\text { investors }\end{array}$} & \multicolumn{2}{|c|}{$\begin{array}{c}\text { Size of assets } \\
\text { (bln US dollars) }\end{array}$} & \multicolumn{2}{|c|}{$\begin{array}{l}\text { Size of investment assets } \\
\text { (bln US dollars) }\end{array}$} \\
\hline & $\begin{array}{c}\text { As of } \\
\text { January } \\
01,2019 \\
\end{array}$ & $\begin{array}{l}\text { As of January } \\
01,2020\end{array}$ & $\begin{array}{l}\text { As of January } \\
01,2019\end{array}$ & $\begin{array}{c}\text { As of January } \\
01,2020\end{array}$ & $\begin{array}{l}\text { As of January } \\
01,2019\end{array}$ & $\begin{array}{c}\text { As of January } \\
01,2020\end{array}$ \\
\hline $\begin{array}{l}\text { Integrated Accumulative } \\
\text { Pension Fund }\end{array}$ & 1 & 1 & 9,51 & 12,53 & 9,28 & 12,39 \\
\hline Investment funds & 259 & 223 & 2,15 & 2,43 & 2,15 & 2,43 \\
\hline Banking sector & 19 & 20 & 80,06 & 77,83 & 5,57 & 11,71 \\
\hline Insurance sector & 44 & 41 & 1,81 & 2,00 & 1,34 & 1,40 \\
\hline $\begin{array}{l}\text { Professional players of } \\
\text { the securities market }\end{array}$ & 103 & 83 & 3,00 & 1,18 & 0,93 & 0,40 \\
\hline
\end{tabular}

As judged by the data from the table,the investment funds dominate in the structure of institutional investors of the republican market, and during the period under review, their number decreased by 36 units, amounting to 223 units in 2019.

The second place is occupied by the brokers and dealers (professional players of the securities market). In 2019, their number constituted 83 persons, having decreased by 20 units compared to 2018 .

The last place in the structure is occupied by the institutional investors, excluding the Integrated Accumulative Pension Fund and the representatives of the banking sector; however, in the securities market of Kazakhstan, this group is characterized as the most stable and most capitalized one. For the period under review, the banking sector has expanded its presence in the market both in absolute and relative terms. In 2019 , the number of banking participants in the market increased by one unit and amounted to 20 participants. The size of the investment assets of the bank has also increased, having constituted11,71 bln US dollars in 2019.

As of January 01, 2020, the total capitalization of the market of non-public securitiesincluded in the official listing of KASE constituted 11650,9 bln tenge (78,48 bln US dollars), having increased on bonds by 2 times for 2019 (from 1520,8 bln tenge as of January 01, 2019 to 3 141,7bln tenge as of January01, 2020), on shares - by 2,3 times (from 3 756,2 bln tengeas of January01, 2019 to 8506,2 bln tengeas of January01, 2020), which can be judged in detail by the figure below.

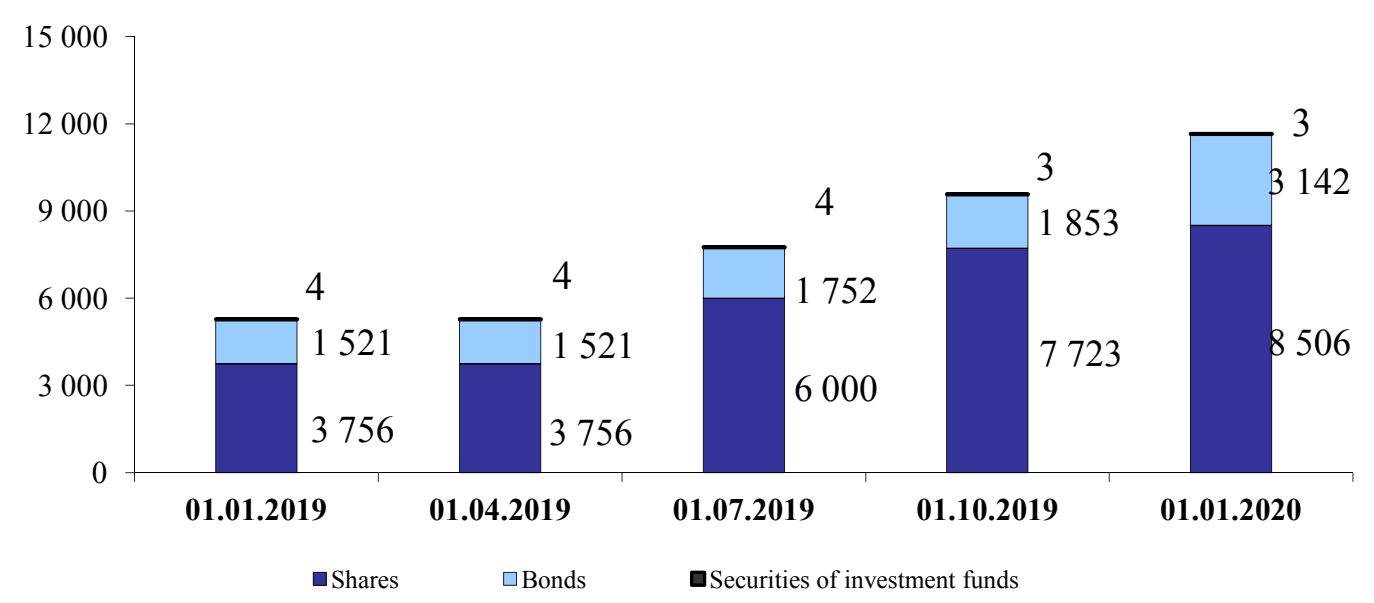

Figure3. Dynamics of change in the KASE capitalization, bln tenge. 
As of January 01, 2020, the total market capitalizationon non-public securities included in the official listing of KASE increased by 2,2 times compared to the same period in 2019 (Fig. 3).

The growth in the capitalization of the stock market in absolute terms influenced the increase in the ratio of this indicator to GDP (Fig. 4).

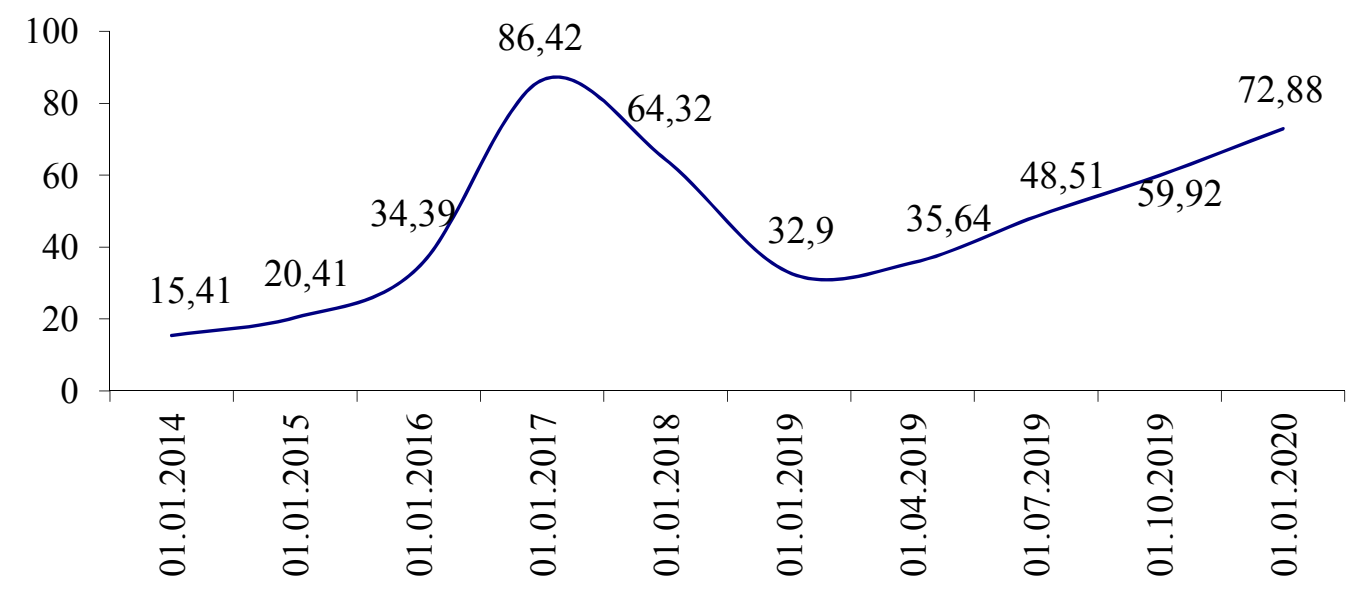

Figure4. KASE capitalization toGDP, \%.

Note - prepared by the authors based on (Agal'tsova, 2020, 153)

The mainrelative share of securities admitted to trading at KASE corresponds to the debt securities $71,5 \%$ (249 issues), by sector shares and securities of investment funds $-28,2 \%$ (98 issues) and 0,3\% (1 issue),respectively.

As judged by the data of table 2, the lowest relative share in the structure of the registered securities of security issues corresponds to the sector"Securities of investment funds". For the period under review, the number of issuers increased by 3 units and constituted 58 as of January 01, 2020. However, despite the growth in the number of issuers, the number of issues in 2019 decreased significantly and constituted 182 issues as of January 01, 2020. It is 23 issues less than the respective indicator of 2018.

Table 2. Volume and number of the securities issues registered by theregulator of the securities market

\begin{tabular}{|c|c|c|c|c|c|c|}
\hline \multirow{2}{*}{ Types of securities } & \multicolumn{2}{|c|}{ Number of issuers } & \multicolumn{2}{|c|}{ Number of issues } & \multicolumn{2}{|c|}{$\begin{array}{l}\text { CB volume of issue } \\
\text { (bln US dollars) }\end{array}$} \\
\hline & $\begin{array}{l}\text { As of Janu- } \\
\text { ary01, } 2019\end{array}$ & $\begin{array}{l}\text { As of Janu- } \\
\text { ary01, 2020 }\end{array}$ & $\begin{array}{l}\text { As of Janu- } \\
\text { ary01, } 2019\end{array}$ & $\begin{array}{l}\text { As of Janu- } \\
\text { ary01, } 2020\end{array}$ & $\begin{array}{l}\text { As of Janu- } \\
\text { ary01, } 2019\end{array}$ & $\begin{array}{l}\text { As of Janu- } \\
\text { ary01, 2020 }\end{array}$ \\
\hline Sector"Shares" & 22240 & 2196 & 2240 & 2196 & - & - \\
\hline Sector"Debt securities" & 195 & 212 & 347 & 395 & 14,48 & 35,48 \\
\hline $\begin{array}{l}\text { Sector"Securities } \\
\text { ofinvestment funds" }\end{array}$ & 55 & 58 & 205 & 182 & - & \\
\hline Total & 2490 & 2466 & 2792 & 2773 & & \\
\hline
\end{tabular}

The current situation shows that second-tier banks, insurance funds and other financial and credit institutions, as well as enterprises and private investors, are not yet taking active steps, although they have reserves. To overcome this barrier, the state apparatus should ensure the favourable investment climate that would guarantee the potential investors the transparency of the market, its reliability and safety to stimulate the activity of the listed financial institutions as main operators in the republican securities market.

It should also be noted that, considering the fact that our Republic has joined the Common economic union with the Russian Federation, the cooperation between the stock exchanges of Kazakhstan and Russia seems quite promising and mutually beneficial. Kazakhstan has "long" money - money of insurance funds and the Integrated Accumulative Pension Fund. But, due to the peculiarities of the legislative control, this money does not work to the full extent, which indirectly hinders the development of the securities market. The merger of the securities markets of two states could give the popular Russian "short" money, which is more speculative and capable of reviving trade, to the domestic market (Golovnin, 2016, 44). 
In general, the results of the conducted analysis allow to highlight the following problems in the system of government regulation and development of the security markets:

- limited market liquidity;

- deficiencies in laws and other regulatory documents governing the activities of the market subjects;

- lack of high-quality financial instruments;

- low qualification of JSC heads in the field of corporate finance, who do not yet see an alternative to bank loans in the securities market;

- principal shareholders are afraid of losing control over the enterprise if it enters the stock market, refusal of public IPO;

- insufficient transparency of listed companies.

- lack of an effective mechanism for the protection of the rights and interests of investors, in particular, portfolio and small non-professional ones.

For the further development of the domestic securities market, the state, represented by the authorized authorities, shall take the following steps:

1. Expand the list of marketable and reliable financial instruments traded in the domestic stock market.

2. Upgrade the quality of provision of the financial services by improving the work methods of professional players using modern IT technologies while upgrading the quality of the risk management systems (Luque, Páscoa, 2014, 212-213).

3. Increase the responsibility of the issuers and their officials for violation of the terms of issue and placement of bonds.

4. Raise the requirements to the terms of issue of bonds asmarketablefinancial instruments.

5. Establish the issuer's obligation that will make it legally bound to repay the debt to the investors by redeeming the placed bonds at the highest price between the par value taking into account the accumulated compensation and fair market value of a bond;

6. Extend the functions and enhance the roles of a bond holder representative;

7. Assign the additional functions to the Kazakhstan stock exchange in order to monitor the issuers and members of the stock exchange.

\section{Discussion}

Despite the significant scientific groundwork on this problem, the issues of increasing the resilience of the domestic securities market to crisis and the activity of people in its secondary market remain understudied. However, in general, the results of assessing the current market state confirm the correctness of the author's hypothesis that the shift of focus from the issues of legal support of the system of government regulation of the securities market of the Republic of Kazakhstan to the problem of primary transparency and reliability of the market from the point of view of potential investors will serve as an evolutionary trigger of its intensive development.

The reliability of the scientific provisions of the paper is confirmed by the methodological consistency with the basic concepts of the leading domestic and foreign scientists and economists, the representativeness of the statistical sampling, the use of the procedure of theoretical interpretation of the basic terms in the paper (government regulation, securities market, investment climate, evolutionary trigger, intensification of economic development, market capitalization, institutional investors, and financial literacy), as well as the methods adequate to the subject, object, goals, and tasks of the study.

\section{Conclusion}

The synthesis of the processed volume of information allows to make a conclusion that as a result of the study, the authors:

- studied the peculiarities of the securities market as an object of government regulation;

- examined the infrastructural support of the system of government regulation of the security market of the Republic of Kazakhstan;

- analyzed and assessed the current state of the security market of the Republic of Kazakhstan;

- studied the systemic problems of government regulation and development of the market;

- developed and substantiated scientifically the promising areas of reforming the republican securities market and the system of its government regulation. 
The conclusions and proposals made by the authors can be used by the central and local executive authorities during the development of sectoral strategic programs for reforming the system of government regulation and development of the Republic of Kazakhstan.

\section{References}

Abbassi, P., Iyer, R., Peydró, J-L., Tous, F. R. (May 2016). Securities trading by banks and credit supply: Microevidence from the crisis. Journal of Financial Economics, Volume 104, Issues 6. 197-212. Retrieved from http: // www.sciencedirect.com

Agal'tsova, S. (2020). Gosudarstvennoe regulirovanie rynka tsennykh bumag Respubliki Kazakhstan [State regulation of the securities market of the Republic of Kazakhstan]. Astana: Ekonomiks [in Russian].

Erkebaev, R. (2016). Fondovye rynki i birzhevoe delo: uchebnik [Stock markets and stock exchange business: Textbook]. - Almaty: Print-S [in Russian].

Esenov, B. (2019). Problemy i perspektivy razvitiya rynka tsennykh bumag v Kazakhstane [Problems and prospects of development of the securities market in Kazakhstan]. Sayasat [Policy], 4, 59-66 [in Russian].

Golovnin, M. (2016). Perspektivy sovmestnogo razvitiya infrastruktury fondovykh rynkov v stranakh EvrAzES [Prospects for joint development of stock market infrastructure in the EurAsEC countries]. Evraziiskaya ekonomicheskaya integratsiya [Eurasian economic integration] Almaty: EABR, 1(2), $39-46$ [in Russian].

Iskakov, U., Bokhaev, D., \& Ruzieva, E. (2020). Finansovye rynki i posredniki: monografiya [Financial markets and intermediaries: Monograph]. Almaty: Ekonomika, 314 [in Russian].

IS Paragraph "Lawyer" (2020). Zakon Respubliki Kazakhstan «O rynke tsennykh bumag» [Law of the Republic of Kazakhstan "On the securities market"] ot 02.06.2003 goda № 461-II (s izmeneniyami i dopolneniyami po sostoyaniyu na 02.01.2020 g. [with amendments and additions as of 02.01.2020]) // online.zakon.kz [in Russian].

Karagusova, G. (2020). Otchego slabo razvit fondovyi rynok Kazakhstana [Why is the stock market of Kazakhstan poorly developed]. Vestnik KazUEFIT, 2, 54-59 [in Russian].

Miller, R. (2016). Sovremennye metody gosudarstvennogo regulirovaniya finansovogo sektora strany [Modern methods of state regulation of the country's financial sector]. Moscow: INFRA-M [in Russian].

Zhumabekov, L. (2020). Sovershenstvovanie gosudarstvennogo regulirovaniya finansovogo sektora Respubliki Kazakhstan [Improvement of state regulation of the financial sector of the Republic of Kazakhstan]. Delovoi Kazakhstan [Business Kazakhstan], 2, 17-26 [in Russian].

Magill, M., Quinzii M. (July 2011). Normative properties of stock market equilibrium with moral hazard. Journal of Mathematical Economics, Volume 44, Issues 7-8. 785-806. Retrieved from http: // www.sciencedirect.com

Cabán-García, M. (September 2011). The impact of securities regulation on the earnings properties of European crosslisted firms. The International Journal of Accounting, Volume 44, Issue 3. 279-304. Retrieved from http: // www.sciencedirect.com

Bottazzi, J.-M., Luque, J., Páscoa, M.R. (March 2012). Securities market theory: Possession, repo and rehypothecation. Journal of Economic Theory, Volume 147, Issue 2. 477-500. Retrieved from http: // www.sciencedirect.com

Teall, J.L. (June 2013). Regulation of Trading and Securities Markets. Financial Trading and Investing, Volume 147, Issue 2. 93-115. Retrieved from http: // www.sciencedirect.com

Luque, J., Páscoa, M. R. (June 2014). Investor ignorance in markets for worthless stocks. Journal of Financial Markets, Volume 19. 197-218. Retrieved from http: // www.sciencedirect.com

Lohse, T., Pascalau, R. (October 2014). Public enforcement of securities market rules: Resource-based evidence from the Securities and Exchange Commission. Journal of Economic Behavior \& Organization, Volume 106. 197-212. Retrieved from http: // www.sciencedirect.com

\section{Р.Қ. Елшибаев, С.Б. Сауранбай, А.О. Ағымбай}

\section{Қазақстан Республикасының бағалы қағаздар нарығын мемлекеттік реттеу}

\section{Аңдатna}

Maқ̧саты: Қазақстан Республикасының бағалы қағаздар нарығын дамытудың перспективалық бағыттарын айқындау және оны мемлекеттік реттеу жүйесін реформалауды анықтау.

Әдісі: Зерттеуде эмпирикалық, субъективті-объектілік, жүйелік, дедуктивті және салыстырмалы талдау әдістері пайдаланылды. Осы әдістердің әрқайсысы тиісті кезеңдік зерттеу мәселелерін шешу үшін өзінің функционалдық мүмкіндіктері мен қабілеттеріне сәйкес қолданылды.

Қорытылыды: Авторлар жүргізген зерттеу нәтижесінде:

- мемлекеттік реттеу объектісі ретінде бағалы қағаздар нарығының ерекшеліктері зерттелді;

- Қазақстан Республикасының бағалы қағаздар нарығын мемлекеттік реттеу жүйесін инфрақұрылымдық қамтамасыз ету қаралды;

- еліміздің бағалы қағаздар нарығының ағымдағы жағдайы бағаланды;

- мемлекеттік реттеу мен нарықты дамытудың жүйелі проблемалары зерттелді; 
- Қазақстан Республикасының бағалы қағаздар нарығын және оны мемлекеттік реттеу жүйесін реформалаудың перспективалық бағыттары әзірленіп, ғылыми негізделді.

Тұжырымдама: Қазақстан Республикасының бағалы қағаздар нарығын мемлекеттік реттеу жүйесін құқықтық қамтамасыз ету проблемаларынан экономикалық интеграция және жаһандық коронадағдарыс жағдайларында нарықтың бастапқы ашықтығы мен сенімділігі проблемасына ауыстыру мынадай мақсаттарға қол жеткізуге мүмкіндік берді:

- корпоративті эмитенттердің жаңа IPO жүргізу жағдайында акциялар нарығының ЖІӨ капитализациясы екі есе артады;

- ААҚО Азиядағы он жетекші қаржы орталықтарының қатарына кіреді;

- көптеген тұтынушылар тобының қаржылық қызметтерге қолжетімділігі қамтамасыз етіледі;

- нарықтың қатысушыларының жинақтарының сақталуы мен әлеуетті инвесторлардың мүдделерінің қорғалуы, халықтың қаржылық сауаттылығының жоғарылауы қамтамасыз етілетін болады.

Kiлm сөздер: мемлекеттік реттеу, бағалы қағаздар нарығы, инвестициялық климат, нарықтық капиталдандыру, Қазақстан қор биржасы (KASE), институционалдық инвесторлар, нарықтың кәсіби қатысушылары, қаржылық сауаттылық.

\section{Р.Қ. Елшибаев, С.Б. Сауранбай, А.О. Ағымбай}

\section{Государственное регулирование рынка ценных бумаг Республики Казахстан}

Цель: Определение перспективных направлений развития рынка ценных бумаг Республики Казахстан и реформирование системы его государственного регулирования.

Meтоды: В исследовании использованы методы эмпирического, субъектно-объектного, системного, дедуктивного и сравнительного анализа. Каждый из этих методов применялся адекватно своим функциональным возможностям и разрешающим способностям для решения соответствующих стадийных исследовательских задач.

Результаты: В результате проведенного авторами исследования:

- изучены особенности рынка ценных бумаг как объекта государственного регулирования;

- рассмотрено инфраструктурное обеспечение системы государственного регулирования рынка ценных бумаг Республики Казахстан;

- проведена оценка текущего состояния рынка ценных бумаг страны;

- исследованы системные проблемы государственного регулирования и развития рынка;

- разработаны и научно обоснованы перспективные направления реформирования рынка ценных бумаг Республики Казахстан и системы его государственного регулирования.

Bblвoдbl: Смещение акцента с проблем правового обеспечения системы государственного регулирования рынка ценных бумаг Республики Казахстан на проблему первичной прозрачности и надежности рынка в условиях экономической интеграции и глобального коронакризиса позволит достичь следующих целей:

- капитализация рынка акций к ВВП удвоится, если новые IPO будут проводиться корпоративными эмитентами;

- РФЦА войдет в группу десяти ведущих финансовых центров Азии;

- будет организован доступ к финансовым услугам для широкого круга потребителей;

- будут обеспечены повышение финансовой грамотности населения, защита интересов потенциальных инвесторов и сохранность сбережений участников рынка.

Ключевые слова: государственное регулирование, рынок ценных бумаг, инвестиционный климат, рыночная капитализация, Казахстанская фондовая биржа (KASE), институциональные инвесторы, профессиональные участники рынка, финансовая грамотность.

\section{References}

Агальцова С.В. Государственное регулирование рынка ценных Республики Казахстан / С.В. Агальцова. - Астана: Экономикс, 2020. - 282 с.

Головнин М. Перспективы совместного развития инфраструктуры фондовых рынков в странах ЕврАзЭС / М. Головнин // Евразийская экономическая интеграция. - Алматы: ЕАБР, 2016. — 1 (2). — С. 39-46.

Еркебаев Р.К. Фондовые рынки и биржевое дело: учеб. / Р.К. Еркебаев. - Алматы: Принт-С, 2016. — 395 с.

Есенов Б. Проблемы и перспективы развития рынка ценных бумаг в Казахстане / Б. Есенов // Саясат. — 2019. — 4. - С. 59-66.

Жумабеков Л.И. Совершенствование государственного регулирования финансового сектора Республики Казахстан / Л.И. Жумабеков // Деловой Казахстан. - 2020. - 2. - C. 17-26.

ИС Параграф «Юрист» (2020). Закон Республики Казахстан «О рынке ценных бумаг» от 2 июля 2003 года № 461-II (с изм. и доп. по состоянию на 02.01.2020 г.) // online.zakon.kz

Искаков У.М. Финансовые рынки и посредники: моногр. / У.М. Искаков, Д.Т. Бохаев, Э.А. Рузиева. — Алматы: Экономика, 2020. - 314 с. 
Карагусова Г.Д. Отчего слабо развит фондовый рынок Казахстана / Г.Д. Карагусова // Вестн. КазУЭФМТ. 2020. - 2. - С. 53-59.

Миллер Р.Л. Современные методы государственного регулирования финансового сектора страны. - М.: ИНФРА-М, 2016. - $356 \mathrm{c}$.

Special attention should be paid to M. Golovnin (Golovnin, 2016), R. Erkebaev (Erkebaev, 2016), R Miller (2016), L. Zhumabekov (Zhumabekov, 2020), who deal with the study of the processes of merging the markets of Russia and Kazakhstan. The mentioned scientific papers constitute the core methodological basis for understanding the specific features of the organization of the securities market.

The works dedicated to the issues of government regulation and development of the securities market in Kazakhstan include the studies byG. Karagusova (Karagusova,2020), B. Yesenov (Yesenov,2019), S.V. Agaltsova (Agaltsova, 2020), etc. It should be noted that most of the mentioned papers mainly consider ways to improve the well-being of the people by creating a favorable investment climate in the country. They also cover other important issues, but in general, we can speak of the lack of specific proposals that can fundamentally change thecurrent situation in thesecurities market.

Magill, M., Quinzii M. (July 2011). Normative properties of stock market equilibrium with moral hazard. Journal of Mathematical Economics, Volume 44, Issues 7-8. 785-806. Retrieved from http: // www.sciencedirect.com

Cabán-García, M. (September 2011). The impact of securities regulation on the earnings properties of European crosslisted firms. The International Journal of Accounting, Volume 44, Issue 3. 279-304. Retrieved from http: // www.sciencedirect.com

Bottazzi, J.-M., Luque, J., Páscoa, M.R. (March 2012). Securities market theory: Possession, repo and rehypothecation. Journal of Economic Theory, Volume 147, Issue 2. 477-500. Retrieved from http: // www.sciencedirect.com

Teall, J.L. (June 2013). Regulation of Trading and Securities Markets. Financial Trading and Investing, Volume 147, Issue 2. 93-115. Retrieved from http: // www.sciencedirect.com

Luque, J., Páscoa, M. R. (June 2014). Investor ignorance in markets for worthless stocks. Journal of Financial Markets, Volume 19. 197-218. Retrieved from http: // www.sciencedirect.com

Lohse, T., Pascalau, R. (October 2014). Public enforcement of securities market rules: Resource-based evidence from the Securities and Exchange Commission. Journal of Economic Behavior \& Organization, Volume 106. $197-212$. Retrieved from http: // www.sciencedirect.com

Abbassi, P., Iyer, R., Peydró, J-L., Tous, F. R. (May 2016). Securities trading by banks and credit supply: Microevidence from the crisis. Journal of Financial Economics, Volume 104, Issues 6. 197-212. Retrieved from http: // www.sciencedirect.com 